\title{
Incidence of ARDS and outcomes in hospitalized patients with COVID-19: a global literature survey
}

\author{
Susan J. Tzotzos ${ }^{1 *} \mathbb{D}$, Bernhard Fischer ${ }^{1}$, Hendrik Fischer ${ }^{1}$ and Markus Zeitlinger ${ }^{2}$
}

Keywords: ARDS, COVID-19, Hospital, ICU, Incidence, Mortality, SARS-CoV-2

Coronavirus disease 2019 (COVID-19) caused by severe acute respiratory syndrome coronavirus 2 (SARS-CoV-2) appeared just over 7 months ago in Wuhan, China. Early reports from China indicated that although some cases are asymptomatic, $20 \%$ of COVID-19 cases follow a severe course, necessitating hospitalization, with a quarter of hospitalized patients requiring intensive care unit (ICU) facilities [1]. Later reports from China and other countries substantiated these data, although ICU admission rates, proportion of patients receiving invasive mechanical ventilation (IMV), and mortality rates differ considerably between studies [2].

The life-threatening form of respiratory failure, acute respiratory distress syndrome (ARDS) is a frequent complication in COVID-19 [3]. The severity of ARDS is classified into categories of mild, moderate, and severe, depending on the degree of hypoxemia [4]. Patients with moderate-tosevere ARDS require invasive mechanical ventilation (IMV) and have a poor prognosis [4]. The incidence of ARDS and specifically, moderate-to-severe ARDS, among COVID-19 patients is currently unknown [5].

We describe here the results of a survey of clinical studies reporting COVID-19-associated ARDS in hospitalized patients since the beginning of the COVID-19 pandemic in January until the end of July 2020. Our aim was to obtain a clearer picture of the incidence of COVID-19-associated ARDS in hospitalized patients on a global level, to better define the burden to healthcare

\footnotetext{
* Correspondence: s.tzotzos@apeptico.com

${ }^{1}$ Apeptico GmbH, Mariahilfer Strasse 136, 1150 Vienna, Austria

Full list of author information is available at the end of the article
}

systems and to inform critical care clinicians. This information should enable the prediction of requirements for hospital resources and thereby facilitate planning an appropriate and timely response in the future.

We carried out regular searches of PubMed using combinations of the search terms "ARDS," "COVID-19," "clinical characteristics," "clinical features," "clinical findings," "ICU," "incidence," "outcome," and "prevalence" (last search July 31, 2020).

Over 1000 publications were retrieved from which only studies reporting consecutively hospitalized patients, and giving numbers for ARDS patients and outcomes, were selected. Meta-analyses were excluded.

Seventeen studies reporting results from 2486 hospitalized COVID-19 patients in five countries fitted the inclusion criteria (Tables 1 and 2). Limitations are that seven studies did not define ARDS and only one study classified patients as mild, moderate, and/or severe; the patient sample is comparatively small: twelve of the studies had less than 200 patients. Furthermore, there was heterogeneity in types of data gathered by each research group, hence for many of the studies, patient numbers did not permit calculation of all parameters (Tables 1 and 2).

There is variability between individual studies with respect to frequency of ARDS, rates of ICU admission, and mortality among patients. Calculation of weighted averages for these parameters incorporating data from individual studies for which data is available indicate that among hospitalized COVID-19 patients, approximately 1/3 (33\%) develop ARDS, 1/4 (26\%) require transfer to 


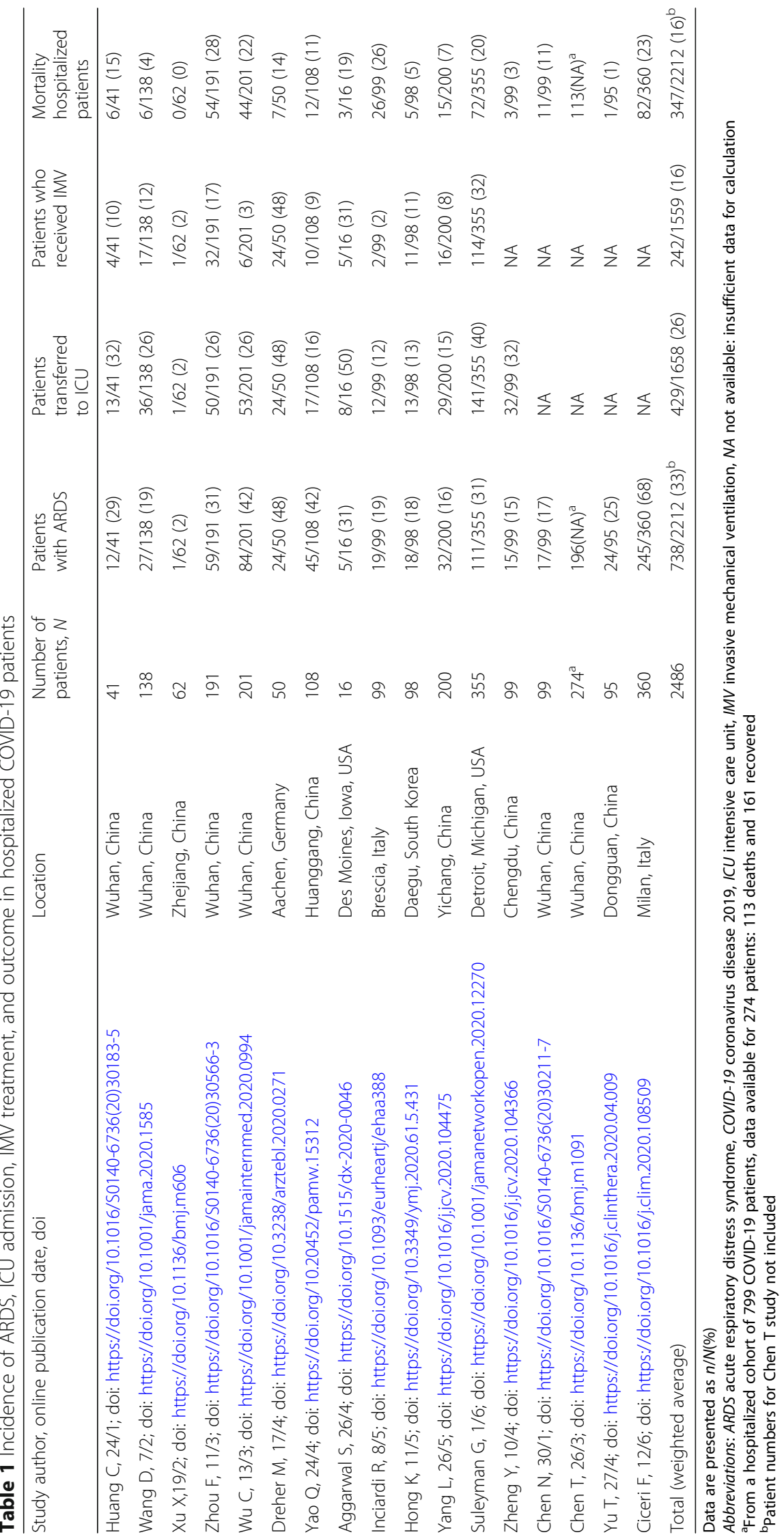


Table 2 Incidence of ARDS, IMV treatment, and outcomes in COVID-19 patients admitted to an ICU

\begin{tabular}{|c|c|c|c|c|c|c|c|}
\hline $\begin{array}{l}\text { Study author, online } \\
\text { publication date }{ }^{a}\end{array}$ & Location & $\begin{array}{l}\text { ICU patients } \\
\text { with ARDS }\end{array}$ & $\begin{array}{l}\text { ICU patients who } \\
\text { received IMV }\end{array}$ & $\begin{array}{l}\text { Mortality ICU } \\
\text { patients }\end{array}$ & $\begin{array}{l}\text { Mortality } \\
\text { ARDS patients }\end{array}$ & $\begin{array}{l}\text { Mortality IMV } \\
\text { patients }\end{array}$ & $\begin{array}{l}\text { Prevalence of ARDS } \\
\text { in non-survivors }\end{array}$ \\
\hline Dreher $M, 17 / 4$ & Aachen, Germany & $24 / 24(100)$ & $24 / 24(100)$ & $3 / 24(13)$ & $3 / 24(13)$ & $3 / 24(13)$ & 3/7 (43) \\
\hline Yao Q, 24/4 & Huanggang, China & $17 / 17(100)$ & 10/17 (59) & $12 / 17(71)$ & $12 / 45(27)$ & 10/10 (100) & $12 / 12(100)$ \\
\hline Hong K, 11/5 & Daegu, South Korea & 13/13 (100) & $11 / 13(85)$ & 4/13 (31) & 4/18 (22) & NA & 4/5 (80) \\
\hline Xu X,19/2 & Zhejiang, China & $1 / 1(100)$ & $1 / 1(100)$ & 0/1 (0) & 0/1 (0) & 0/1 (0) & NA \\
\hline Wu C, 13/3 & Wuhan, China & NA & $6 / 53(11)$ & NA & $44 / 84(52)$ & 6/6 (100) & 44/44 (100) \\
\hline Zhou F, 11/3 & Wuhan, China & NA & NA & $39 / 50(78)$ & $50 / 59(85)$ & $31 / 32(97)$ & $50 / 54(93)$ \\
\hline Zheng $Y, 10 / 4$ & Chengdu, China & $15 / 32(47)$ & NA & $3 / 32(9)$ & $3 / 15(20)$ & NA & 3/3 (100) \\
\hline Suleyman G, 1/6 & $\begin{array}{l}\text { Detroit, Michigan, } \\
\text { USA }\end{array}$ & 104/141 (74) & 114/141 (81) & $57 / 141(40)$ & NA & $52 / 114(46)$ & NA \\
\hline Huang C, 24/1 & Wuhan, China & $11 / 13(85)$ & 4/13 (31) & 5/13 (38) & NA & NA & NA \\
\hline Wang $D, 7 / 2$ & Wuhan, China & $22 / 36(61)$ & $21 / 36(58)$ & 6/36 (17) & NA & NA & NA \\
\hline Yang L, 26/5 & Yichang, China & $21 / 29(72)$ & $16 / 29(55)$ & $14 / 29(48)$ & NA & NA & NA \\
\hline Chen T, 26/3 & Wuhan, China & NA & NA & NA & 113/196 (58) & 17/17 (100) & 113/113 (100) \\
\hline Aggarwal S, 26/4 & $\begin{array}{l}\text { Des Moines, lowa, } \\
\text { USA }\end{array}$ & NA & $5 / 8(63)$ & $3 / 8(38)$ & NA & NA & NA \\
\hline Inciardi R, 8/5 & Brescia, Italy & NA & NA & NA & 17/19 (89) & NA & $17 / 26(65)$ \\
\hline Chen N, 30/1 & Wuhan, China & NA & NA & NA & $11 / 17(65)$ & NA & 11/11 (100) \\
\hline Ciceri F, 12/6 & Milan, Italy & NA & NA & NA & $65 / 245(27)$ & NA & 65/82 (79) \\
\hline Yu T, 27/4 & Dongguan, China & NA & NA & NA & NA & NA & NA \\
\hline Total (weighted average) & & 228/306 (75) & 212/335 (63) & 146/363 (40) & 322/722 (45) & 119/203 (59) & 322/357 (90) \\
\hline
\end{tabular}

Data are presented as $n / N(\%)$

Abbreviations: ARDS acute respiratory distress syndrome, COVID-19 coronavirus disease 2019 , ICU intensive care unit, IMV invasive mechanical ventilation, NA not available: insufficient data for calculation

${ }^{\mathrm{a}}$ For study reference see Table 1

an ICU, $1 / 6(16 \%)$ receive IMV, and $1 / 6(16 \%)$ die (Table 1). For COVID-19 patients transferred to an ICU, nearly $2 / 3$ (63\%) receive IMV and 3/4 (75\%) have ARDS (Table 2). The mortality rate of ICU COVID-19 patients is $40 \%$ and of those who receive IMV 59\%; the mortality rate in COVID-19-associated ARDS is 45\%, and the incidence of ARDS among non-survivors of COVID-19 is 90\% (Table 2). The high incidence of ARDS among COVID-19 patients revealed in our survey is consistent with the results of postmortem examinations of patients with COVID-19, in which the predominant finding is diffuse alveolar damage, the most frequent histopathologic correlate of ARDS.

For as long as there is neither a safe and efficacious vaccine nor therapy for severely affected COVID-19 patients, standard supportive care with lung-protective mechanical ventilation will be the cornerstone of treatment for these patients $[5,6]$. The implications of these survey results are important and demonstrate the considerable challenges posed by the "COVID-19 crisis" to ICU practitioners, hospital administrators, and health policy makers.

Susan Tzotzos, MSc, PhD

Bernhard Fischer, PhD
Hendrik Fischer, $\mathrm{PhD}$

Markus Zeitlinger, MD, PhD

\section{Abbreviations}

ARDS: Acute respiratory distress syndrome; COVID-19: Coronavirus disease 2019; ICU: Intensive care unit; IMV: Invasive mechanical ventilation; SARS-CoV2: Coronavirus 2

\section{Acknowledgements}

Not applicable

\section{Authors' contributions}

SJT conducted the literature search and survey. SJT, BF, and HF evaluated and contributed to the interpretation and presentation of the data. SJT drafted the manuscript; $\mathrm{BF}, \mathrm{HF}$, and $\mathrm{MZ}$ revised the final version of the manuscript. The authors read and approved the final manuscript.

\section{Funding}

This study received funding support from the European Commission (EC), Grant No. 101003595 and from the Austrian Research Promotion Agency (FFG), Grant No.880862.

\section{Availability of data and materials}

Data generated or analyzed during this study are included in this published article.

Ethics approval and consent to participate

Not applicable

Consent for publication

All authors have approved the manuscript for submission. 


\section{Competing interests}

The authors declare that they have no competing interests.

\section{Author details}

${ }^{1}$ Apeptico GmbH, Mariahilfer Strasse 136, 1150 Vienna, Austria. ${ }^{2}$ Department of Clinical Pharmacology, Medical University of Vienna, Waehringer Guertel 18-20, 1090 Vienna, Austria.

Received: 7 August 2020 Accepted: 12 August 2020

Published online: 21 August 2020

\section{References}

1. Wu Z, McGoogan JM. Characteristics of and important lessons from the coronavirus disease 2019 (COVID-19) outbreak in China: summary of a report of 72314 cases from the Chinese Center for Disease Control and Prevention. JAMA. 2020. https://doi.org/10.1001/jama.2020.2648.

2. Wunsch H. Mechanical ventilation in COVID-19: interpreting the current epidemiology. Am J Respir Crit Care Med. 2020;202(1):1-4. https://doi.org/ 10.1164/rccm.202004-1385ED.

3. Wu C, Chen X, Cai Y, et al. Risk factors associated with acute respiratory distress syndrome and death in patients with coronavirus disease 2019 pneumonia in Wuhan, China. JAMA Intern Med. 2020. https://doi.org/10, 1001/jamainternmed.2020.0994

4. Definition Task Force ARDS, Ranieri VM, Rubenfeld GD, et al. Acute respiratory distress syndrome: the Berlin Definition. JAMA. 2012;307(23): 2526-33. https://doi.org/10.1001/jama.2012.5669.

5. Fan E, Beitler JR, Brochard L, et al. COVID-19-associated acute respiratory distress syndrome: is a different approach to management warranted? Lancet Respir Med. 2020:S2213-2600(20)30304-0. https://doi.org/10.1016/ S2213-2600(20)30304-0.

6. Matthay MA, Aldrich JM, Gotts JE. Treatment for severe acute respiratory distress syndrome from COVID-19. Lancet Respir Med. 2020;8(5):433-4. https://doi.org/10.1016/S2213-2600(20)30127-2

\section{Publisher's Note}

Springer Nature remains neutral with regard to jurisdictional claims in published maps and institutional affiliations.

- fast, convenient online submission

- thorough peer review by experienced researchers in your field

- rapid publication on acceptance

- support for research data, including large and complex data types

- gold Open Access which fosters wider collaboration and increased citations

- maximum visibility for your research: over $100 \mathrm{M}$ website views per year

At $\mathrm{BMC}$, research is always in progress.

Learn more biomedcentral.com/submissions 